CHI-CHUNG TAO, Ph.D. ${ }^{1}$

(Corresponding author)

E-mail: cctao@mail.tku.edu.tw

CHIEH-CHIH FAN, M.S. ${ }^{1}$

E-mail: ajerry77fan@gmail.com

${ }^{1}$ Tamkang University,

Department of Transportation Management

Tamsui District, New Taipei City, 25137, Taiwan
Human - Transport Interaction

Preliminary Communication

Submitted: 26 Feb. 2016

Accepted: 21 Sep. 2016

\title{
A MODIFIED DECOMPOSED THEORY OF PLANNED BEHAVIOUR MODEL TO ANALYZE USER INTENTION TOWARDS DISTANCE-BASED ELECTRONIC TOLL COLLECTION SERVICES
}

\begin{abstract}
This study proposes a modified decomposed theory of planned behaviour model (DTPB) that integrates satisfaction and trust into the original DTPB model to explore what kind of factors affect the user intention towards distance-based electronic toll collection (ETC) services. The proposed model is empirically tested by using data collected from a questionnaire survey with a computer assisted telephone interview system. Empirical analysis is carried out in three stages that combine confirmatory factor analysis, structural equation modelling (SEM), and Bayesian network: (1) examination of reliability and validity of the measurement model; (2) analysis of structural model; (3) prediction of the probability of user intention change based on rigorous framework of SEM. The results confirm that the satisfaction and trust have positive effects on the behaviour intention, also validating that five constructs have indirect effects on the behaviour intention through attitude and perceived behaviour control. Compatibility is the most important influence factor, followed by perceived usefulness, facilitating conditions, self-efficacy, and perceived ease of use. The findings of this study identify potential improvements for ETC operator, such as contributing to the society to enhance the company image and trust of enterprise with charity activities, and simultaneously up grading the information platform of website, software, and Apps.
\end{abstract}

\section{KEY WORDS}

decomposed theory of planned behaviour; structural equation modelling; Bayesian network; distance-based electronic toll collection;

\section{INTRODUCTION}

Electronic toll collection (ETC) is an automated system, eliminating manual operations by toll payers and receivers. From 2015 to 2020 the global ETC market is expected to steer towards a strong double-digit growth rate [1]. Most of drivers of the upcoming growth comprise the need to save travel time, cashless travel facility, the need to stop to minimize the traffic congestion and fast toll transaction. In general, the ETC market can be categorized into products, technologies, applications and geographies. On the basis of technologies, the ETC market can be divided into various categories, such as radio-frequency identification (RFID), dedicated short-range communications (DSRC), video analytics, global navigation satellite system (GNSS) including global positioning system (GPS), global navigation satellite system (GLONASS), Galileo, Beidou and quasi zenith satellite system (QZSS). Currently, RFID and DSRC are the leading technologies worldwide. However, GNSS is expected to show a high growth rate in the following five years.

As to ETC applications, highway, urban and bridges are now very common. Undoubtedly, ETC systems have been installed majorly on highways, but the installation in urban areas and on bridges has a bright future opportunity. Geographically, the ETC market can be segmented into North America, Latin America, Asia Pacific, Japan, Western Europe, Eastern Europe, and Middle East \& Africa. The present market scenario represents a strong presence of ETC system in the US, Canada and Mexico in North America, South Korea, Taiwan, Thailand, Malaysia, Hong Kong, Philippines and Singapore in Asia Pacific, and the UK, Ireland, Portugal, France, Germany, Italy and Spain in Europe.

In 2015, the International Bridge, Tunnel and Turnpike Association (IBTTA) announced the results of its annual toll excellence awards competition, and Taiwan area national freeway bureau (TANFB) was the winner for the category of customer service \& marketing outreach with the "Program for transition from manual flat-rate pay-per-use toll collection to electronic distance-based toll collection". The TANFB explained that since the introduction of the "private sector involvement in development of ETC system" with Far Eastern Electronic Tolling Company (FETC) team in 2003, it has adopted a two-stage implementation: from manual flat-rate pay-per-use toll collection to electronic distance-based system to increase fairness and equity across the highway network, boost operational 
efficiency, streamline traffic flow through variable pricing, and deliver superior accuracy. The agency introduced manual and electronic tolling in February 2006 , followed by a tag of radio frequency identification (eTag) system in May 2012, and now averages 14 million transactions per day with a tolling accuracy rate of $99.97 \%$ and detection accuracy of $99.9 \%$, the world's highest. The eTag system consists of 319 single gantries that feature a modular design for rapid deployment. It took only 10 months to install all the gantries, with no on-the-job accidents or loss in quality. At present, more than 6 million vehicles have installed eTag (94\%) in Taiwan.

Owing to the relentless efforts of the FETC team, Taiwan has become the first country in the world to successfully make such a tolling system migration. Statistically, since the launch of ETC, with more efficient traffic, saving of fuel and reduction of $\mathrm{CO}_{2}$ emission etc., the total benefits for the society amount to about US $\$ 0.75$ billion [2]. With the implementation of ETC, Taiwan's freeway has reached a new frontier and become world-renowned. This also allowed Taiwan to reach the threshold of intelligent electronic toll collection and advanced traffic management.

Since Taiwan's ETC services are provided by a private company FETC which is regulated by the government, FETC has to be reviewed to achieve the standard of satisfaction and utilization. Complaints of dissatisfaction from eTag users so far still exist, which means that the high utilization rate is not equal to the high degree of satisfaction or high level of trust towards enterprise operating ETC services. Therefore, how to improve the eTag users' level of satisfaction and find the degree of influence between trust and satisfaction are current interesting issues for FETC and TANFB.

The distance-based ETC system provides emerging eTag functions which provide a brand new experience to freeway users in Taiwan. The type of new ETC services adopted by eTag users and influence factors will consider whether the new ETC services can successfully narrow the gap. Previous studies concerned with intelligent transportation systems (ITS) or advanced traveller information systems (ATIS) or ETC take the perspective of user intention to explain and predict the influence factors for adoption of new systems or services in terms of user intention behaviour through the technology acceptance model (TAM) $[3,4,5,6]$ or the theory of planned behaviour (TPB) $[7,8]$ or combined TAM with TPB models [9]. Several empirical studies conclude that the decomposed theory of planned behaviour (DTPB) is a rigorous behaviour theory with new technology and acceptance for intention to predict by considering multiple influence factors [10, 11 , 12]. However, literature on the study of how various distance-based ETC services influence the acceptance of specific eTag users based on DTPB are quite rare at the present time.
In view of this a modified behaviour intention model based on DTPB has been proposed in this study as a rigorous theoretical basis. For empirical study an analytical process is implemented to summarize various opinions or perspectives from eTag users by questionnaire surveys on the users' satisfaction, which connects with structural equation modelling (SEM) and Bayesian network (BN) to identify and verify the eTag users' behaviour intention changes on the satisfaction of ETC and operator's trust.

\section{THEORETICAL BACKGROUND}

\subsection{Decomposed theory of planned behaviour (DTPB) model}

In TPB, the attitude (AT), subjective norms (SN), perceived behaviour control (PBC) are affected by human behavioural beliefs, and the relationship among the three constructs is not necessarily significant. To more reasonably explain and to predict human behaviour on different conditions, Taylor and Todd [10] proposed the DTPB model to decompose the uni-dimensional belief constructs into multidimensional belief constructs. As shown in Figure 1, the individual's beliefs including attitude, subjective norms, and perceived behaviour control are the three most important factors explaining new technology adoption behaviour.

The attitude is decomposed into the three constructs which included perceived usefulness, perceived ease of use, and compatibility with innovation diffusion theory on personal perception of technology innovation. The perceived usefulness refers to the degree to which the users believe that using a specific application system will increase their job performance. The perceived ease of use refers to the degree to which users believe that using a specific application system is easy and convenient. Compatibility indicates the innovative acceptance which fits the current values, past experiences, and actual degree of demand for potential acceptors.

The DTPB is a kind of improved behaviour model which is based on the innovation diffusion theory (IDT), TPB, TAM, and it adopts the multidimensional belief structure to study individual antecedents of constructs. Therefore, it is very resilient to consider multiple impact factors for adoption of the technology [13], and it can help the operators or managers to conceive the factor of affecting the consumers' behaviour.

Ajzen [14] points out the insignificance among the three constructs due to uni-dimensional influence. The uni-dimensional construct probably contains all influences of beliefs, and it will produce the counterbalance to the positive and negative beliefs which simultaneously exist in the same dimensional construct. Therefore, the subjective norms are decomposed into 


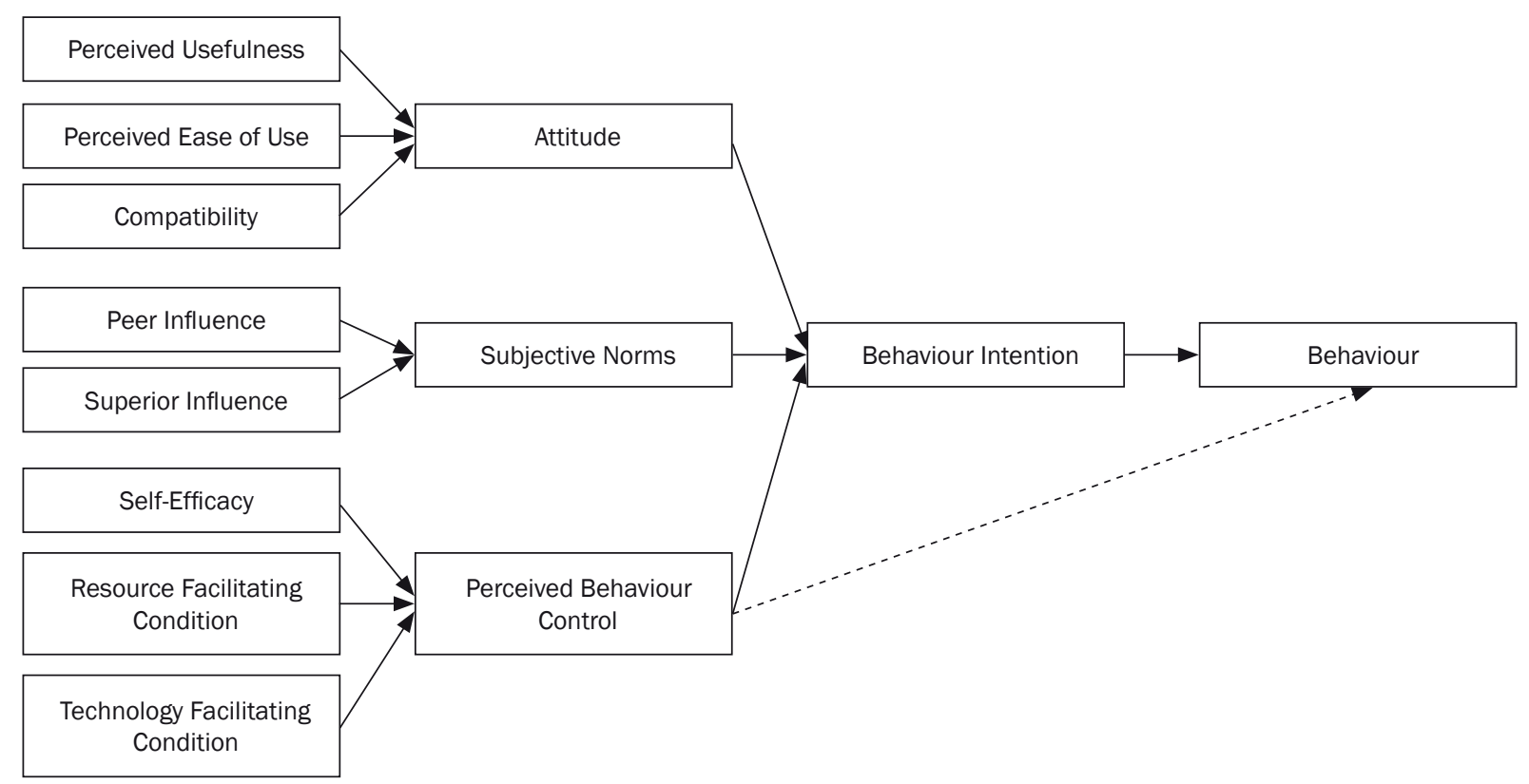

Figure 1 - The original DTPB Model

two constructs which contain peer influence and superior influence from normative beliefs $[15,16]$. Peer influence indicates the perspectives from friends and colleagues. Superior influence represents the perspectives and perceptions from predecessors and superiors.

Perceived behaviour control is decomposed into two constructs based on the Ajzen's research that include self-efficacy and facilitating condition which is decomposed into the resource facilitating condition and the technology facilitating condition. Self-efficacy represents an ability to perform the specific behaviour by selves. Resource facilitating condition and technology facilitating condition are the external resource limitations of two parts of capital and technique.

\subsection{Modified DTPB model}

According to the introduction of Taiwan's ETC market, the aim of this study is the modelling of the relationships among the degree of satisfaction with ETC services for eTag users and the trust of the ETC operator from the users' viewpoint. The original DTPB model is modified by combining two constructs of satisfaction and trust which are shown in Figure 2. Further, an attempt is made to render the modified DTPB model more valid to describe eTag users' actual behaviour intention. The advantages of the modified DTPB model are as follows: firstly, it can clearly realize the relationship between antecedents and belief constructs. Secondly, it can correctly point out the possible specific

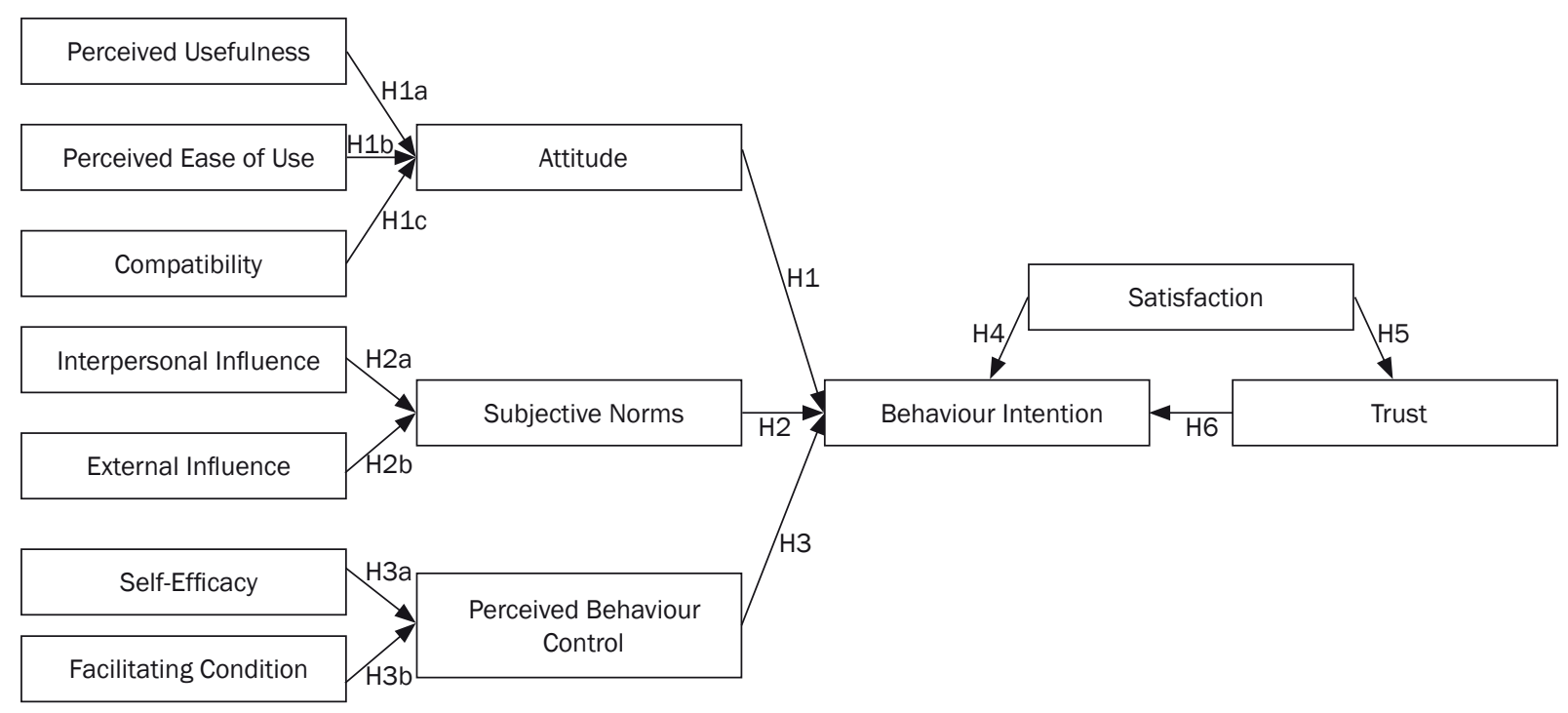

Figure 2 - The modified DTPB model 
behaviour factor to be applied to different scenarios, and thirdly, it can prevent the positive and negative beliefs from referring to a single construct effect.

\subsection{Research hypotheses}

Previous studies conclude that IDT is a process to understand the innovations and how to widely apply them in the society system [17]. According to IDT in the field of applying innovations of personnel, there are five perceived characteristics of innovation: relative advantages, compatibility, complexity, trialability, observability [18]. Most of the studies declare that relative advantages and compatibility increase the application of the information technology [10]. The concept of relative advantages is similar to perceived usefulness [19], and the concept of complexity is similar to perceived ease of use [20]. Thus, whether in technologies or services of the distance-based ETC system, the eTag system is regarded as a kind of transportation innovation in Taiwan.

Typical for TPB application of the information system only contains normative influences [10, 21]. Therefore, in the field of electronic retail, the normative belief was decomposed into two constructs, interpersonal influence and external influence from Bhattacherjee [22]. The interpersonal influence includes family, friends, and parents, and the external influence includes media reports, opinion of experts, advertisements on television, and online word-of-mouth. This study considers the adoption and choice of eTag from users that will be affected by various information resources in the era of high development.

In the previous study, the perceived behaviour control has been separated into internal self-efficacy and external resource limitations which point out less time-consumption and less money cost that enhance the degree of perceived behaviour control of users [10]. Consequently, if eTag users need to understand the complicated process of service and do not know how to earn the service of operation or installing, they will decrease the degree of acceptance of eTag and then unload their eTag label from original equipment of users.

According to TPB, if someone has positive attitude for a specific behaviour, the specific behaviour may have a higher behaviour intention. In terms of subjective norms, if consumers execute a specific behaviour with more positive attitude, they will have higher intention of the specific behaviour. Moreover, perceived behaviour control is the resource limitation which includes internal and external in executing specific behaviour. If there are fewer restrictions, the user's ability to control the behaviour will be higher. According to DTPB, attitude, subjective norms and perceived behaviour control have significant positive effects on the behaviour.

Many previous studies demonstrated the importance of satisfaction in behaviour assessment, showing that it has positive effect on the behaviour intention and trust [23-25]. Satisfaction has been noted as a special form of consumer attitude. It is a post purchase phenomenon to reflect how much the consumer likes or dislikes the service after experiencing it [25]. Such as experience-based, global attitude construct as customer satisfaction should strongly influence the connective constructs, such as behaviour intention and repeat purchase behaviour. Hence, customer satisfaction has been proposed as an important hypothetical construct in models of consumer purchase behaviour.

Cronin et al. [26] found a positive relationship between customer satisfaction and behaviour intentions. Bolton and Drew [27] also confirmed the satisfaction which had positive influence on customer post-purchasing behaviour. Hutchinson et al. [28] validated that traveller's satisfaction has significant positive effect on the behaviour intention of revisiting a golf course.

Trust is a degree of response to the satisfaction of customers. Therefore, Singh and Sirdeshmukh [25] divided the trust construct into two parts which consisted pre-purchase performance expectations and post-purchase performance evaluations among agency and trust mechanisms, and it validated that the satisfaction had significant positive effect on post-purchase performance evaluations.

Trust is an important belief of maintaining the social cooperation, and it is also a necessary foundation for daily routine interaction [29]. Moreover, trust is generalized loyalty which includes actual behavioural loyalty and emotional cognitive loyalty. In the field of e-commerce, when consumers trust the internet trading partner, it not only has a positive beneficial effect on purchasing behaviour, but also contributes to a positive beneficial effect on the subsequent transaction or online purchase behaviour. The online trust influences the reliability of data from internet, and further affects the online purchase behaviour intention [30-32]. The relationship between trust and behaviour intention is also verified by the research done by Garbarino and Johnson [24].

In summary, the research hypotheses derived from the modified DTPB model according to aforementioned literature inferences can be listed as follows:

H1a: Perceived usefulness positively affects the eTag users' attitude.

H1b: Perceived ease of use positively affects the eTag users' attitude.

H1c: Compatibility positively affects the 
eTag users' attitude.

$\mathrm{H} 2 \mathrm{a}$ : Interpersonal influence positively affects the eTag users' subjective norms.

$\mathrm{H} 2 \mathrm{~b}$ : External influence positively affects the eTag users' subjective norms.

H3a: Self-efficacy positively affects the eTag users' perceived behaviour control.

H3b: Facilitating conditions positively affect the eTag users' perceived behaviour control.

H1: Behavioural attitude of eTag positively affects the eTag users' behaviour intention of adoption.

H2: Subjective norms of eTag positively affect the eTag users' behaviour intention of adoption.

H3: Perceived behaviour control of eTag positively affects the eTag users' behaviour intention of adoption.

H4: Satisfaction of ETC products and services positively affects the eTag users' behaviour intention of adoption.

H5: Satisfaction of ETC products and services positively affects the trust of ETC operator.

H6: Trust of ETC operators positively affects the eTag users' behaviour intention of adoption.

\section{RESEARCH DESIGN}

\subsection{Questionnaire survey}

A questionnaire survey is conducted to collect data of eTag users and the questions of questionnaire are designed with references to relevant theoretical literature to attain the objectivity of data in questionnaire quality. A pre-test survey is also conducted with a pilot sample of 30 eTag users to further increase the validity of questionnaire before the formal questionnaire.

The questionnaire consists of three parts. The first part is structural equation modelling (SEM)-related questions in which respondents need to indicate their agreement level for each question. The responses to these questions in each construct were measured by five-point Likert-type scale from 1 point indicating "highly disagree" to 5 points indicating "highly agree".

The perceived usefulness construct is measured by four questions derived from Davis et al. [19]. The perceived ease-of-use construct is measured by six questions and the compatibility construct is measured by three questions which are all derived from Taylor and Todd [10]. The interpersonal influence construct is measured by four questions and the external influence construct is measured by five questions which are all derived from Bhattcherjee [22]. The self-efficacy and facilitating condition constructs are measured by three questions derived from Taylor and Todd [10], and Bhattcherjee [22], respectively. The attitude and perceived behaviour control constructs are measured by three questions which are all derived from Aaker [33] and Bhattcherjee [22]. The subjective norms construct is measured by three questions derived from Ajzen [34]. The behaviour intention construct is measured by five questions derived from the related studies [22, 33]. The satisfaction construct is measured by four questions derived from Zeithaml and Bitner [35] and Anderson et al. [36]. Eventually, the trust construct is measured by six questions derived from McKnight et al. [37].

The second part of the questionnaire is a set of scenario questions of Bayesian network which is constructed with the relationship of path of construct by the specific scenario, and the responses of a set of questions to predict the transfer probability under hypothetical assumptions. The third part describes the basic information of the respondents, including gender, age, education level, monthly income, trip purpose, and frequency of use on the freeway.

\subsection{Sampling and data collection}

The data collection of eTag users is conducted by using a computer-assisted telephone interview (CATI) system. With the help of CATI, the interview process is standardized and the randomness of the process to collect more complete data is also minimized. Due to conditions of normalized assumptions of structural equation modelling it is necessary to maintain a certain scale of samples [38]. We hypothesize 5\% confidence interval and set $95 \%$ confidence level to calculate the sample size for 385 samples with registered plate numbers by the sampling formula. The sampling method of CATI in this study is stratified random sampling procedure with the following steps: (1) Deciding the sampling proportion from registration of the residential address of vehicles to get individual sample size of counties in Taiwan. (2) Distinguishing the counties sampling sizes into four regions. (3) Executing random sampling in four regions. All valid samples are distributed to four regions including northern, central, southern, and eastern Taiwan according to regional percentage of total registered plate numbers.

\section{EMPIRICAL ANALYSIS AND RESULTS}

\subsection{Descriptive statistics}

The demographic profile of 400 respondents can be summarized in Table 1 . As shown in Table 1, the adults aged $31-50$ (63.3\%) are the major eTag user group, and the monthly income is centred between 40,001 to 60,000 (41.8\%). Geographically, most of the respondents live in the northern region (56.3\%). The common trip purposes are commuting (41.5\%) 
and business (36\%). The frequency of use on freeway is concentrated in 11 days or above per month (64\%).

Table 1 - The demographic profile of the respondents $(N=400)$

\begin{tabular}{|c|c|c|}
\hline & Frequency & Percentage [\%] \\
\hline \multicolumn{3}{|l|}{ Place of residence } \\
\hline Northern & 225 & 56.3 \\
\hline Central & 75 & 18.8 \\
\hline Southern & 68 & 17.0 \\
\hline Eastern & 32 & 8.0 \\
\hline \multicolumn{3}{|l|}{ Gender } \\
\hline Male & 276 & 69.0 \\
\hline Female & 124 & 31.0 \\
\hline \multicolumn{3}{|l|}{ Age } \\
\hline $18 \sim 20$ & 1 & 0.3 \\
\hline $21 \sim 30$ & 86 & 21.5 \\
\hline $31 \sim 40$ & 145 & 36.3 \\
\hline $41 \sim 50$ & 108 & 27.0 \\
\hline 51 or above & 60 & 15.0 \\
\hline \multicolumn{3}{|l|}{ Education level } \\
\hline Senior high school & 86 & 21.5 \\
\hline College/University & 263 & 65.8 \\
\hline Graduate school & 51 & 12.7 \\
\hline \multicolumn{3}{|l|}{ Monthly income (NTD) } \\
\hline Less than 20,000 & 31 & 7.8 \\
\hline $20,001 \sim 40,000$ & 60 & 15.4 \\
\hline $40,001 \sim 60,000$ & 167 & 41.8 \\
\hline $60,001 \sim 80,000$ & 64 & 16.1 \\
\hline 80,000 or above & 78 & 19.1 \\
\hline \multicolumn{3}{|l|}{ Trip purpose } \\
\hline Commuting & 166 & 41.5 \\
\hline Business & 144 & 36.0 \\
\hline Returning home & 21 & 5.3 \\
\hline Leisure & 69 & 17.2 \\
\hline \multicolumn{3}{|c|}{ Frequency of use on freeways } \\
\hline 1-2 Days/Month & 47 & 11.8 \\
\hline 3-10 Days/Month & 97 & 24.3 \\
\hline $\begin{array}{l}11 \text { Days or above/ } \\
\text { Month }\end{array}$ & 256 & 64.0 \\
\hline
\end{tabular}

\subsection{Item analysis}

Item analysis refers to a statistical technique that helps this study to identify the effectiveness of the questionnaire items. The value of critical ratio is computed to compare the significance of mean difference in each question. The critical ratio of scale questionnaire is a total test score which is divided into higher test scores (top 27\%) and lower test scores (end 27\%) to determine a criterion for deleting the question. This study tests the significance of the F value and variance from population by using the independent-sample t test and the Levene's test. The Levene's test is an inferential statistics to assess the equality of variances for a variable calculation for two or more groups. Having run the item analysis, all items of the questionnaire in this study are significant for testing the significance by $p$-value of Levene's test $(p<0.05)$ and $p$-value of independent-sample test $(p<0.05)$. It demonstrates that all items of the questionnaire are discriminative with valid results of statistical tests.

\subsection{Confirmatory Factor analysis}

The two main factor analysis techniques are exploratory factor analysis (EFA) and confirmatory factor analysis (CFA). CFA attempts to confirm the hypotheses and uses path analysis diagrams to represent variables and factors, whereas EFA tries to uncover complex patterns by exploring the dataset and testing predictions. CFA is used to test the adequacy of measurement model with SPSS and AMOS software tools. Prior to the extraction of the factors, several tests should be used to assess the suitability of the respondent data for factor analysis. These tests include Kaiser-Meyer-Olkin (KMO) measure of sampling adequacy, and Bartlett's test of sphericity. The KMO index, in particular, is recommended when the cases to variable ratio are less than 1:5. The KMO index ranges from 0 to 1 , with 0.50 considered suitable for factor analysis. And the Bartlett's test of sphericity also should be significant $(p<.05)$ for the factor analysis to be suitable.

As shown in Table 2, the statistical results are calculated with IBM SPSS Statistics 20 software. The p-value of total question items in the questionnaire is 0.000 , and the results of the latent variables are statistically significant which indicate that each KMO value is basically greater than 0.60 and factor loading of variable is equal to or greater than 0.50 . However, there are two observational variables (II4 \& TR6) must be deleted due to non-significant lower factor loading values.

\subsection{Reliability and validity analysis}

Reliability is a measurement of stability for questionnaires, and the Cronbach's $\alpha$ value is a measure of internal consistency, that is, how closely related a set of items are as a group. High $\alpha$ value denotes high internal consistency in all variables. In general the $\alpha$ value must reach at least 0.70 or higher to derive acceptable factor. As shown in Table 3, the Cronbach's $\alpha$ values in this study range from 0.767 to 0.951 which represent relatively higher internal consistency among the items of the questionnaire. Construct reliability is then estimated to test the internal consistency in a set of latent construct indicators. Table 3 
C.-C. Tao, C.-C. Fan: A Modified Decomposed Theory of Planned Behaviour Model to Analyze User Intention towards Distance-Based...

Table 2 - Measurement model results

\begin{tabular}{|c|c|c|c|c|c|}
\hline Latent variables & Observational variables & Factor loading & KMO & Standard error & $t$-value \\
\hline \multirow{4}{*}{$\begin{array}{l}\text { Perceived } \\
\text { Usefulness }\end{array}$} & PU1 & 0.865 & \multirow{4}{*}{0.798} & 0.063 & $18.508 * * *$ \\
\hline & PU2 & 0.898 & & 0.063 & $19.327 * * *$ \\
\hline & PU3 & 0.785 & & 0.045 & $16.439 * * *$ \\
\hline & PU4 & 0.862 & & - & - \\
\hline \multirow{6}{*}{$\begin{array}{l}\text { Perceived } \\
\text { Ease of Use }\end{array}$} & PEU1 & 0.806 & \multirow{6}{*}{0.808} & 0.189 & $16.903 * * *$ \\
\hline & PEU2 & 0.800 & & 0.192 & $9.567 * * *$ \\
\hline & PEU3 & 0.806 & & 0.178 & $9.913 * * *$ \\
\hline & PEU4 & 0.828 & & 0.154 & $9.829 * * *$ \\
\hline & PEU5 & 0.725 & & 0.056 & $9.797 * * *$ \\
\hline & PEU6 & 0.741 & & - & - \\
\hline \multirow{3}{*}{ Compatibility } & COM1 & 0.751 & \multirow{3}{*}{0.675} & 0.206 & $9.152 * * *$ \\
\hline & COM2 & 0.846 & & 0.109 & $11.248 * * *$ \\
\hline & $\mathrm{COM} 3$ & 0.795 & & - & - \\
\hline \multirow{4}{*}{$\begin{array}{l}\text { Interpersonal } \\
\text { Influence }\end{array}$} & II1 & 0.904 & \multirow{4}{*}{0.770} & 0.030 & $31.693 * * *$ \\
\hline & 112 & 0.925 & & - & - \\
\hline & 113 & 0.914 & & 0.027 & $37.087 * * *$ \\
\hline & H4 & 0.336 & & & \\
\hline \multirow{5}{*}{$\begin{array}{l}\text { External } \\
\text { Influence }\end{array}$} & El1 & 0.790 & \multirow{5}{*}{0.834} & 0.039 & $26.704 * * *$ \\
\hline & $\mathrm{El} 2$ & 0.852 & & 0.035 & $31.380 * * *$ \\
\hline & $\mathrm{El} 3$ & 0.877 & & - & - \\
\hline & EI4 & 0.829 & & 0.040 & $21.842 * * *$ \\
\hline & El5 & 0.626 & & 0.061 & $9.738 * * *$ \\
\hline \multirow{3}{*}{ Self-Efficacy } & SE1 & 0.938 & \multirow{3}{*}{0.765} & 0.040 & $27.501 * * *$ \\
\hline & SE2 & 0.949 & & 0.040 & $27.598 * * *$ \\
\hline & SE3 & 0.925 & & - & - \\
\hline \multirow{3}{*}{$\begin{array}{l}\text { Facilitating } \\
\text { Conditions }\end{array}$} & FC1 & 0.839 & \multirow{3}{*}{0.705} & 0.080 & $13.482 * * *$ \\
\hline & FC2 & 0.876 & & 0.099 & $12.969 * * *$ \\
\hline & FC3 & 0.815 & & - & - \\
\hline \multirow{3}{*}{ Attitude } & AT1 & 0.921 & \multirow{3}{*}{0.700} & 0.080 & $15.442 * * *$ \\
\hline & AT2 & 0.925 & & 0.079 & $15.407 * * *$ \\
\hline & AT3 & 0.824 & & - & - \\
\hline \multirow{3}{*}{$\begin{array}{l}\text { Subjective } \\
\text { Norms }\end{array}$} & SN1 & 0.819 & \multirow{3}{*}{0.724} & 0.058 & $15.203 * * *$ \\
\hline & SN2 & 0.871 & & 0.063 & $16.905 * * *$ \\
\hline & SN3 & 0.878 & & - & - \\
\hline \multirow{3}{*}{$\begin{array}{l}\text { Perceived Behaviour } \\
\text { Control }\end{array}$} & PBC1 & 0.896 & \multirow{3}{*}{0.743} & 0.038 & $24.908 * * *$ \\
\hline & PBC2 & 0.948 & & 0.032 & $33.034 * * *$ \\
\hline & PBC3 & 0.936 & & - & - \\
\hline & $\mathrm{BI} 1$ & 0.792 & & 0.067 & $17.375 * * *$ \\
\hline & $\mathrm{BI} 2$ & 0.834 & & 0.047 & $19.946 * * *$ \\
\hline Behaviour Intention & $\mathrm{BI} 3$ & 0.886 & 0.874 & - & - \\
\hline & $\mathrm{BI} 4$ & 0.891 & & 0.054 & $21.216 * * *$ \\
\hline & $\mathrm{BI} 5$ & 0.762 & & 0.066 & $15.868 * * *$ \\
\hline & $\mathrm{S} 1$ & 0.757 & & 0.058 & $13.807 * * *$ \\
\hline Satisfaction & S2 & 0.865 & 0789 & - & - \\
\hline Satistaction & S3 & 0.881 & 0.109 & 0.048 & $19.622 * * *$ \\
\hline & S4 & 0.707 & & 0.073 & $15.367 * * *$ \\
\hline & TR1 & 0.820 & & 0.063 & $15.592 * * *$ \\
\hline & TR2 & 0.916 & & 0.060 & $19.491 * * *$ \\
\hline Trust & TR3 & 0.910 & 0887 & 0.051 & $22.719 * * *$ \\
\hline Irust & TR4 & 0.836 & 0.881 & - & - \\
\hline & TR5 & 0.841 & & 0.055 & $18.596 * * *$ \\
\hline & FRG & $\theta .457$ & & & \\
\hline
\end{tabular}

Note: $* \star \star p<0.01$ 
shows that the construct reliabilities for all constructs in the measurement model of this study range from 0.840 to 0.956 , exceeding the cut-off value 0.6 recommended by Bagozzi and Yi [39].

Table 3 - Results of reliability and validity

\begin{tabular}{|c|c|c|c|}
\hline \multirow[b]{2}{*}{$\begin{array}{l}\text { Latent } \\
\text { variables }\end{array}$} & \multicolumn{3}{|c|}{ Indices of testing } \\
\hline & $\begin{array}{c}\text { Cronbach's } \\
\alpha \\
(>0.7)\end{array}$ & $\begin{array}{c}\text { Construct } \\
\text { Reliability } \\
\qquad(>0.6)\end{array}$ & $\begin{array}{c}\text { Average } \\
\text { Variance } \\
\text { Extraction } \\
(>0.5)\end{array}$ \\
\hline $\begin{array}{l}\text { Perceived } \\
\text { Usefulness }\end{array}$ & 0.884 & 0.915 & 0.728 \\
\hline $\begin{array}{l}\text { Perceived Ease } \\
\text { of Use }\end{array}$ & 0.887 & 0.906 & 0.617 \\
\hline Compatibility & 0.767 & 0.840 & 0.637 \\
\hline $\begin{array}{l}\text { Interpersonal } \\
\text { Influence }\end{array}$ & 0.951 & 0.939 & 0.836 \\
\hline $\begin{array}{l}\text { External } \\
\text { Influence }\end{array}$ & 0.896 & 0.898 & 0.640 \\
\hline Self-Efficacy & 0.936 & 0.956 & 0.879 \\
\hline $\begin{array}{l}\text { Facilitating } \\
\text { Conditions }\end{array}$ & 0.802 & 0.881 & 0.712 \\
\hline Attitude & 0.895 & 0.920 & 0.794 \\
\hline $\begin{array}{l}\text { Subjective } \\
\text { Norms }\end{array}$ & 0.844 & 0.892 & 0.733 \\
\hline $\begin{array}{l}\text { Perceived } \\
\text { Behaviour } \\
\text { Control }\end{array}$ & 0.934 & 0.948 & 0.859 \\
\hline $\begin{array}{l}\text { Behaviour } \\
\text { Intention }\end{array}$ & 0.926 & 0.920 & 0.696 \\
\hline Satisfaction & 0.880 & 0.880 & 0.649 \\
\hline Trust & 0.926 & 0.937 & 0.749 \\
\hline
\end{tabular}

In addition to the reliability test, construct validity is used to assess the quality of an instrument or experimental design. Researchers usually establish both of the two main types of construct validity, convergent and discriminant, for their constructs. Convergent validity is tested by examining the factor loadings and item reliability through CFA in this study. As shown in Table 2 and Table 3, the statistical significance on the factor loading estimation for each item can be determined by the $t$-value based on the literature recommendations. The $t$-values of convergent validity range from 9.154 to 31.087 , exceeding the critical value 1.96 recommended by literature in this study and each item exceeds the critical value at the 0.001 significance level.

In terms of discriminant validity, the average variance extracted (AVE) measures the amount of variance that is captured by the construct in relation to the amount of variance due to measurement error. The average variance extractions for all constructs are greater than 0.5 recommended by Fornell and Larcker
[40], indicating that more than one half of the variances in the items can be explained by their latent construct rather than the measurement error. Results of above statistical analysis reveal that all observational items are sufficient to identify latent variables in the modified DTPB model.

\subsection{SEM Analysis}

This study tests the research hypotheses using SEM and applies the suggestions of test results to prepare a comprehensive description on the construct relationship of test results. The SEM analysis of the modified DTPB model is conducted by analyzing the path coefficient of construct relationships. This study follows the process of overall model fit measurement which contains three assessments: absolute fit measurement, incremental fit measurement and parsimonious fit measurement recommended by Hair et al. [41]. In terms of the original fit indices of this model, it is not good enough to adapt the real world as shown in Table 4. Thus, this study modifies the path model by erasing the non-significant paths $(\mathrm{H} 2 \mathrm{a} \& \mathrm{H} 2 \mathrm{~b})$ and by adding the connection of residual covariance from recommendation by literature to achieve better results of fit indices.

It is found that the p-value of the chi-square is 0.000 . As shown in Table 4, the $p$-value should generally be less than 0.05 to indicate an adequate fit, but the chi-square value is very sensitive to sample size and frequently causes rejection of a well-fitting model. Therefore, the normed chi-square $\left(x^{2} / d f\right)$ value is often a better indictor than chi-square. An acceptable level of the $x^{2} / d f$ value is a critical value below 3.84. The normed chi-square value of the measurement model on absolute fit measurement of this study is 2.272 , indicating a good fit. The goodness-of-fit index (GFI), adjusted goodness-of-fit index (AGFI), and root mean square error of approximation (RMSEA) are 0.853, 0.811 , and 0.056 , respectively, indicating an acceptable or a reasonable fit, although these indices of absolute fit measurement do not completely approach the test standard. As regards incremental fit measurement, it consists of normed fit index (NFI), relative fit index (RFI), incremental fit index (IFI), non-normed fit index (NNFI), and comparative fit index (CFI), which are $0.886,0.861,0.933,0.917$, and 0.932, respectively. These indices approximate or exceed the recommended value of 0.9. Finally, the parsimonious fit measurement consists of parsimonious NFI (PNFI), parsimonious CFI (PCFI), and parsimonious GFI (PGFI), which are $0.724,0.761$, and 0.664 , respectively. These three indicators exceed the recommended value of 0.9 , providing further support for the measurement model. In summary, the outcome of the model fit measurement 
C.-C. Tao, C.-C. Fan: A Modified Decomposed Theory of Planned Behaviour Model to Analyze User Intention towards Distance-Based...

Table 4 - Model fit measurements

\begin{tabular}{|c|c|c|c|c|c|}
\hline \multirow{2}{*}{$\begin{array}{c}\text { Statistic } \\
\text { Measurement }\end{array}$} & \multirow{2}{*}{ Test Indices } & \multirow{2}{*}{ Test Standard } & \multicolumn{2}{|c|}{ Results } & \multirow{2}{*}{$\begin{array}{l}\text { Model Fit Verifi- } \\
\text { cation }\end{array}$} \\
\hline & & & original & modified & \\
\hline \multirow{4}{*}{$\begin{array}{l}\text { Absolute Fit } \\
\text { Measurement }\end{array}$} & RMSEA & $\leqq 0.08$ & 0.082 & 0.056 & $\checkmark$ \\
\hline & GFI & $\geqq 0.90$ & 0.729 & 0.853 & $\Delta$ \\
\hline & AGFI & $\geqq 0.90$ & 0.694 & 0.811 & $\triangle$ \\
\hline & $x^{2} / d f$ & $\leqq 3.84$ & 3.710 & 2.272 & $\checkmark$ \\
\hline \multirow{4}{*}{$\begin{array}{l}\text { Incremental Fit } \\
\text { Measurement }\end{array}$} & $\mathrm{NFI}$ & $\geqq 0.90$ & 0.783 & 0.886 & $\triangle$ \\
\hline & RFI & $\geqq 0.90$ & 0.766 & 0.861 & $\triangle$ \\
\hline & $\mathrm{IFI}$ & $\geqq 0.90$ & 0.832 & 0.933 & $\checkmark$ \\
\hline & NNFI & $\geqq 0.90$ & 0.818 & 0.917 & $\checkmark$ \\
\hline \multirow{4}{*}{$\begin{array}{l}\text { Parsimonious Fit } \\
\text { Measurement }\end{array}$} & $\mathrm{CFI}$ & $\geqq 0.90$ & 0.831 & 0.932 & $\checkmark$ \\
\hline & PNFI & $\geqq 0.50$ & 0.727 & 0.724 & $\checkmark$ \\
\hline & PCFI & $\geqq 0.50$ & 0.772 & 0.761 & $\checkmark$ \\
\hline & PGFI & $\geqq 0.50$ & 0.624 & 0.664 & $\checkmark$ \\
\hline
\end{tabular}

indicates a good fit between the collected data and the proposed measurement model.

Given the satisfactory performance in model fit measurement of the structural model, the coefficients of path analysis are subsequently examined to evaluate the proposed hypotheses. Calculations with AMOS 17.0 software, Figure 3 and Table 5 show that the perceived usefulness, perceived ease of use, and compatibility, these constructs have significantly positive effects on attitude $(\beta=0.338, t$-value $=7.467, p<0.001$, $\beta=0.184, t$-value $=3.725, p<0.001$, and $\beta=0.370$, $t$-val ue $=6.096, p<0.001$, respectively), thus supporting $\mathrm{H} 1 \mathrm{a}, \mathrm{H} 1 \mathrm{~b}$, and $\mathrm{H} 1 \mathrm{c}$. Both the constructs of self-efficacy and facilitating conditions have significantly positive effects on perceived behaviour control $(\beta=0.218, t$-val$u e=4.472, \quad p<0.001$, and $\beta=0.233, t$-value $=4.409$, $p<0.001$, respectively), supporting $\mathrm{H} 3 \mathrm{a}$ and $\mathrm{H} 3 \mathrm{~b}$. As expected, the attitude has a significantly positive effect on behaviour intention $(\beta=0.321, t$-value $=6.797$, $p<0.001$ ), supporting $\mathrm{H} 1$. The subjective norms have a significantly positive effect on behaviour intention ( $\beta=0.291, t$-value $=5.849, p<0.001$ ), supporting $\mathrm{H} 2$. The perceived behaviour control has a significantly positive effect on behaviour intention $(\beta=0.100, t$-val$u e=2.417, p<0.05$ ), supporting $H 3$. The satisfaction has a significantly positive effect on behaviour intention and trust $(\beta=0.298, t$-value $=5.478, p<0.001$, and $\beta=0.299$, $t$-value $=5.197, p<0.001$, respectively), supporting $\mathrm{H} 4$ and $\mathrm{H} 5$. In addition, trust has a significantly positive effect on behaviour intention ( $\beta=0.093, t$-value $=2.042, p<0.05$ ), supporting $\mathrm{H} 6$.

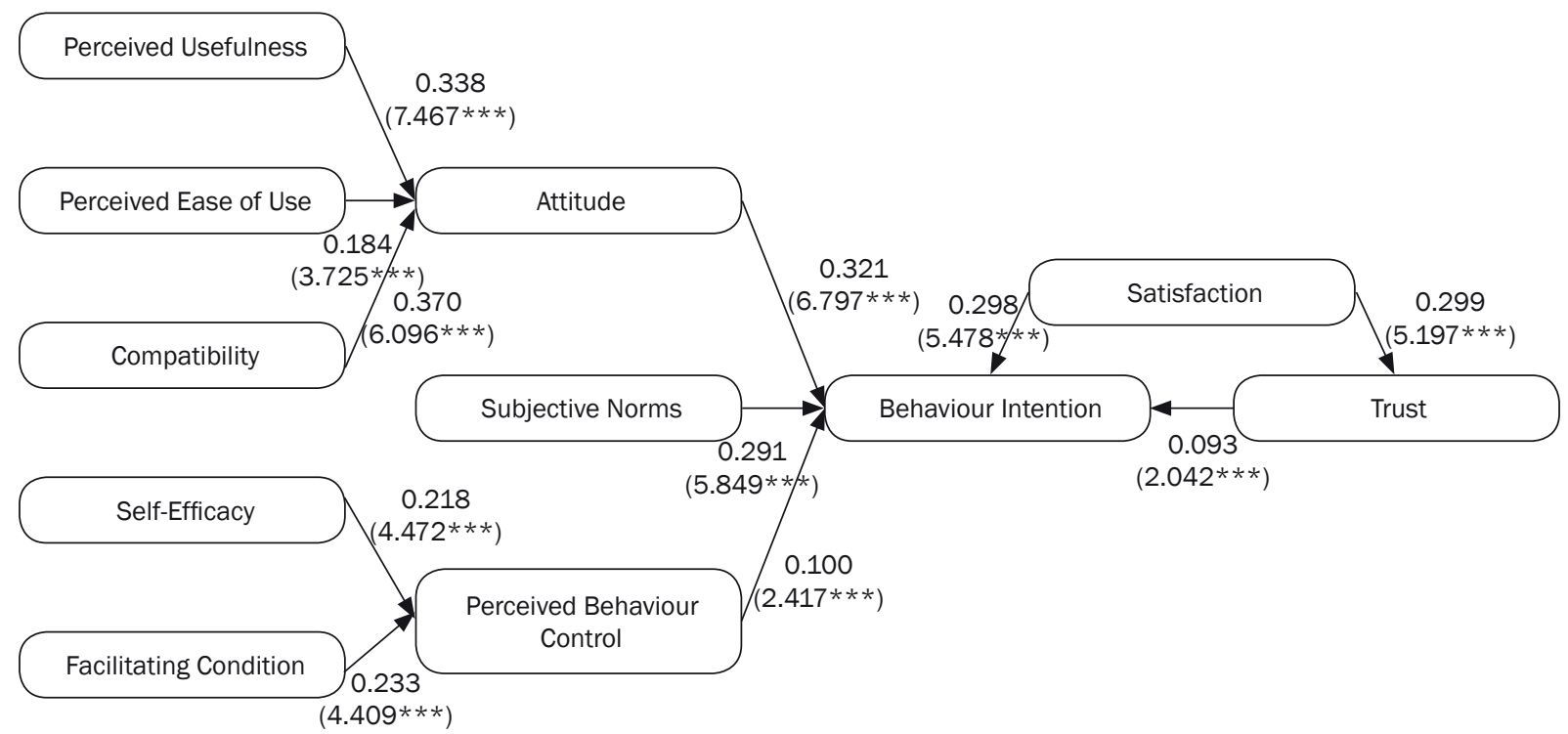

Figure 3 - Overview of Structural equation modelling with path analysis results 
Table 5 - Parameter results of path analysis

\begin{tabular}{|c|c|c|c|c|c|}
\hline Path Relationship & Estimate & Standard Error & $\begin{array}{l}\text { Critical Ratio } \\
\text { (t-value) }\end{array}$ & $\begin{array}{c}\text { Standardized } \\
\text { Regression Weights }\end{array}$ & Test Results \\
\hline Perceived Usefulness $\rightarrow$ Attitude & 0.377 & 0.051 & $7.467 * * *$ & 0.338 & significant \\
\hline Perceived Ease of Use $\rightarrow$ Attitude & 0.290 & 0.078 & $3.725 * * *$ & 0.184 & significant \\
\hline Compatibility $\rightarrow$ Attitude & 0.566 & 0.093 & $6.096 * * *$ & 0.370 & significant \\
\hline $\begin{array}{l}\text { Interpersonal Influence } \rightarrow \text { Subjeetive- } \\
\text { Norms }\end{array}$ & 0.039 & 0.083 & 0.472 & 0.637 & $\begin{array}{c}\text { Not } \\
\text { signifieant }\end{array}$ \\
\hline External Influence $\rightarrow$ Subjective Norms & 0.091 & 0.087 & 1.047 & 0.295 & $\begin{array}{c}\text { Not } \\
\text { signifieant }\end{array}$ \\
\hline $\begin{array}{l}\text { Self-Efficacy } \rightarrow \text { Perceived Behaviour } \\
\text { Control }\end{array}$ & 0.197 & 0.044 & $4.472 * * *$ & 0.218 & significant \\
\hline $\begin{array}{l}\text { Facilitating Conditions } \rightarrow \text { Perceived } \\
\text { Behaviour Control }\end{array}$ & 0.306 & 0.069 & $4.409 * * *$ & 0.233 & significant \\
\hline Attitude $\rightarrow$ Behaviour Intention & 0.296 & 0.044 & $6.797 * * *$ & 0.321 & significant \\
\hline $\begin{array}{l}\text { Subjective Norms } \rightarrow \text { Behaviour } \\
\text { Intention }\end{array}$ & 0.240 & 0.041 & $5.849 * * *$ & 0.291 & significant \\
\hline $\begin{array}{l}\text { Perceived Behaviour Control } \rightarrow \\
\text { Behaviour Intention }\end{array}$ & 0.082 & 0.034 & $2.417 *$ & 0.100 & significant \\
\hline Satisfaction $\rightarrow$ Trust & 0.320 & 0.058 & $5.478 * * *$ & 0.298 & significant \\
\hline Satisfaction $\rightarrow$ Behaviour Intention & 0.289 & 0.056 & $5.197 * * *$ & 0.299 & significant \\
\hline Trust $\rightarrow$ Behaviour Intention & 0.084 & 0.041 & $2.042 *$ & 0.093 & significant \\
\hline
\end{tabular}

Notes: ${ }^{*} p<0.05 . * * p<0.01 . * * * p<0.001$

This study also considers the effect of mediation on the path model. It is found that the path model has a partial mediation effect on trust between the satisfaction and the behaviour intention.

\subsection{Bayesian network analysis}

The modified DTPB model is constructed with SEM analysis which takes account of statistical methodologies to estimate the causal relationships linking two or more latent variables. A scenario questionnaire consisting of question sets is then conducted to understand how eTag user intention will be changed if the ETC operator improves unsatisfied services. Since Bayesian network is a powerful tool for scenario analysis and prediction, this study uses SEM to establish the base path network by theoretical literature, and carries on the construct prediction by $\mathrm{BN}$ with a priori probability and conditional probability with WEKA software.

Since data pre-processing is the top priority of BN analysis, this study recalculates and classifies the scores from the question sets of scenario questionnaire. The scenario hypothesis is "Will the behaviour intention of using eTag and services be enhanced if the ETC operator improves the unsatisfied services related to eTag users?". The scores of constructs having parent node are divided into the new respondents' perceived degree that contains three different average levels (strong, normal, weak). Thus, the continuous data of this study are converted into the discrete data to reduce the computing difficulties. Having identified the constructs with parent nodes that influence the end node(s) in the Bayesian network proposed by this study, the conditional probability tables are then built and the network is analyzed quantitatively based on various scenarios.

As shown in Table 6, for instance, if the ETC operator improves the unsatisfied services related to attitude, the probability of strong willingness to use by eTag users might have $38.43 \%$ possibility of the behaviour intention to use eTag and its relevant services, which increases $6.34 \%$ from the original probability of $32.09 \%$. Moreover, if the ETC operator simultaneously improves the unsatisfied items related to attitude and perceived behaviour control, the probability of strong willingness to use by eTag users might have $43.81 \%$ possibility of the behaviour intention to use eTag and its relevant services, which increases by $11.72 \%$ from the original probability of $32.09 \%$.

In addition, this study also conducts the transferred probability analysis on satisfaction and trust. If the ETC operator improves the unsatisfied items related to satisfaction at the same time, the probability of strong willingness to use by eTag users might increase $9.91 \%$ possibility of the behaviour intention to use eTag and its relevant services, which is from $32.09 \%$ to $42.00 \%$.

The better improvement effect with two constructs seems to be indicative of the fact that the eTag user intention can be significantly enhanced if the ETC operator improves the unsatisfied services related to more than two constructs. 
Table 6 - Results of Bayesian network analysis

\begin{tabular}{|c|c|c|c|c|c|}
\hline $\begin{array}{l}\text { Predicted } \\
\text { Construct }\end{array}$ & $\begin{array}{l}\text { Improved } \\
\text { Constructs }\end{array}$ & $\begin{array}{l}\text { Degree of } \\
\text { Perception }\end{array}$ & $\begin{array}{l}\text { Original } \\
\text { Probability } \\
\text { (before) }\end{array}$ & $\begin{array}{l}\text { Predicted } \\
\text { Probability } \\
\text { (after) }\end{array}$ & $\begin{array}{c}\text { Transfer } \\
\text { Probability }\end{array}$ \\
\hline \multirow{18}{*}{$\begin{array}{l}\text { Behaviour intention to } \\
\text { use eTag and its relevant } \\
\text { services }\end{array}$} & \multirow{3}{*}{ Attitude } & Strong & $32.09 \%$ & $38.43 \%$ & $6.34 \%$ \\
\hline & & Normal & $40.95 \%$ & $41.08 \%$ & $0.13 \%$ \\
\hline & & Weak & $26.95 \%$ & $20.48 \%$ & $-6.47 \%$ \\
\hline & \multirow{3}{*}{$\begin{array}{l}\text { Perceived behaviour } \\
\text { control }\end{array}$} & Strong & $32.09 \%$ & $34.49 \%$ & $2.40 \%$ \\
\hline & & Normal & $40.95 \%$ & $40.24 \%$ & $-0.71 \%$ \\
\hline & & Weak & $26.95 \%$ & $25.26 \%$ & $-1.69 \%$ \\
\hline & \multirow{3}{*}{$\begin{array}{l}\text { Attitude \& Perceived } \\
\text { behaviour control }\end{array}$} & Strong & $32.09 \%$ & $43.81 \%$ & $11.72 \%$ \\
\hline & & Normal & $40.95 \%$ & $30.04 \%$ & $-10.91 \%$ \\
\hline & & Weak & $26.95 \%$ & $25.77 \%$ & $-1.18 \%$ \\
\hline & \multirow{3}{*}{ Satisfaction } & Strong & $32.09 \%$ & $35.69 \%$ & $3.60 \%$ \\
\hline & & Normal & $40.95 \%$ & $32.60 \%$ & $-8.35 \%$ \\
\hline & & Weak & $26.95 \%$ & $31.69 \%$ & $4.74 \%$ \\
\hline & \multirow{3}{*}{ Trust } & Strong & $32.09 \%$ & $34.65 \%$ & $2.56 \%$ \\
\hline & & Normal & $40.95 \%$ & $29.28 \%$ & $-11.67 \%$ \\
\hline & & Weak & $26.95 \%$ & $36.06 \%$ & $9.11 \%$ \\
\hline & \multirow{3}{*}{ Satisfaction \& Trust } & Strong & $32.09 \%$ & $42.00 \%$ & $9.91 \%$ \\
\hline & & Normal & $40.95 \%$ & $28.46 \%$ & $-12.49 \%$ \\
\hline & & Weak & $26.95 \%$ & $29.53 \%$ & $2.58 \%$ \\
\hline
\end{tabular}

\section{CONCLUSION}

Based on extensive literature reviews of DTPB, SEM, and BN, this study proposes a modified DTPB model to identify critical characteristics affecting user intention towards distance-based ETC services. This study confirms the results of related studies in different contexts, and shows good applicability of the modified DTPB model in explaining the user intention of eTag services by SEM analysis. The results validate that five constructs have indirect effects on the behaviour intention through attitude and perceived behaviour control. Compatibility is the most important influence factor, followed by perceived usefulness, facilitating conditions, self-efficacy, and perceived ease of use.

It is found that interpersonal influence and external influence do not significantly affect the path to the subjective norms. One reason for this is that some new car buyers did not need to contact the ETC operator to install their eTags which have been embedded in the new cars from the car factory. The other reason is that some users seldom communicate with FETC's call centre or contact FETC's staff to deal with payment problems.

This study also confirms the partial mediation effect on trust between the satisfaction and the behaviour intention on structural equation modelling. The results show that the respondents might be influenced by public opinion, company reputation, and company image. Moreover, according to results of SEM and BN analysis the trust of the enterprise plays a partial role between satisfaction and behaviour intention. It is found that the satisfaction of ETC products and services can directly influence the behaviour intention to use eTag and its relevant services, but cannot completely influence the behaviour intention through trust of the enterprise. It means most of eTag users are only concerned about the satisfaction of products and services to further influence their behaviour intention.

The meaningful insights and implications presented in this study can help FETC and TANFB develop effective promotion strategies and plans to enhance user intention to use eTag. Firstly, for the perceived ease of use and compatibility FETC should provide a multifunctional information platform and the real-time short messages reminders. Secondly, FETC should communicate with government to strengthen the flexibility of toll fare standards for facilitating conditions and simplify the complexity of operating the interactive telephone voice system for self-efficacy. Thirdly, FETC should participate in more charity activities to enhance a positive company image, and further enrich the user experiences to achieve the users' trust of the enterprise.

Although this study validates the modified DTPB model to have an equivalent degree of adequacy for real world, further details about eTag user behaviour intention will be required by using big data analysis. Because the relative importance of each antecedent 
in predicting behaviour intention may change over time as users gain more experience. Future research can apply integrated task-technology fit (TTF) model and introduce the involvement theory from marketing science to validate the change of behaviour intention. In addition, the sentiment analysis of Internet public opinions on eTag topics can also determine which model can better explain the eTag users' behaviour intention.

\section{陶治中，范傑智}

\section{一種修正的分解式計畫行為理論模式應用於電子計程收費 服務之使用者意向分析}

\section{摘要}

本研究旨在提出一種修正的分解式計畫行為理論模式, 將 滿意度與信任度納入原有的分解式計畫行為理論模式而探 討何種因素會影響電子計程收費服務之使用者意向。藉由 電腦輔助電訪系統之問卷調查結果, 可用於驗證此一修正 模式。驗證分析係採用主成分因素分析、結構方程式與貝 式網路等方法而分為三個階段 : (1) 檢核模式參數的有效 性與可靠性; (2) 進行結構方程式分析; (3) 在結構方程式框 架下預測使用者意向改變的機率。經由態度與有感的行 為控制, 模式輸出結果證實滿意度與信任感對行為意向有 正向效果, 也確認五個構面對行為意向有間接效果。共通 性是最重要的影響因子, 接著是有感的實用性、設備狀 況、自我效能以及有感的易用性。本研究發現結果可確 認對電子收費公司有益的潛在改善項目, 如增加公益活 動, 提升公司形象以及更新網站、軟體、手機應用之資訊 平台。

\section{關鍵詞 \\ 分解式計畫行為理論; 結構方程模式; 貝式網路; 電子計程 收費}

\section{REFERENCES}

[1] Markets and Markets. Electronic toll collection market by type (ETC and AET), product (AVI and AVC), technology (RFID, DSRC, video analytics, and GNSS/ GPS), application (highway and urban) and geography - analysis \& forecast (2014-2020). Markets and Markets [Internet]. 2015 June [cited 2016 January 4]. Available from: http://www.marketsandmarkets.com/ Market-Reports/electronic-toll-collection-system-market-224492059.html

[2] Lo R. Toll excellence award winners - Taiwan Area National Freeway Bureau. FETC [Internet]. 2015 August [cited 2016 February 10]. Available from: http://www. linkedin.com/pulse/2015-toll-excellence-award-winners-taiwan-area-national-robin-lo?forceNosplash=true

[3] Xu C, Wang W, Chen J, Wang W, Yang C. Li, Z. Analyzing travelers' intention to accept travel information. Transportation Research Record. 2010;2156:93-100. doi:http://dx.doi.org/10.3141/2156-11

[4] Lin TW, Lin CY, Hsu WH. Effects of system characteristics on adopting web-based advanced traveller information system: evidence from Taiwan. Promet - Traffic \& Transportation. 2014;26(1):53-63. doi:http://dx.doi.org/10.7307/ptt.v26i1.1224
[5] Jou RC, Chen CC, Ke JC. The influences of evaluation changes from different world-of-mouth channels on the acceptance intention of ETC policy by highway users in Taiwan. Paper presented at: 12th World Conference on Transport Research; 2010 July 11-15; Lisbon, Portugal.

[6] Meesilapawikkai W, Suksawang P, Naenna T. Factors affecting the adoption of electronic toll collection technology. In: Blecker T, editors. Pioneering supply chain design: a comprehensive insight into emerging trends, technologies and applications. Lohmar: Josef Eul Verlag. 2012; p. 161-178.

[7] Vlassenroot S, Brookhuis K, Marchau V, Witlox F. Towards defining a unified concept for the acceptability of intelligent transport systems (ITS): a conceptual analysis based on the case of intelligent speed adaptation (ISA). Transportation Research Part F: Traffic Psychology and Behaviour. 2010;13(3):164-178. doi: 10.1016/j.trf2010.02.001

[8] Veiga Simão J. Impacts of advanced travel information systems on travel behaviour: Smartmoov' case study [PhD thesis]. Torino, institutional repository of the Politecnico di Torino; 2014. doi:10.6092/polito/ porto/2543412

[9] Chen CD, Fan YW, Farn CK. Predicting electronic toll collection service adoption: an integration of the technology acceptance model and the theory of planned behavior. Transportation Research Part C: Emerging Technologies. 2007;15(5):300-311. doi: 10.1016/ j.trc.2007.04.004

[10] Taylor S, Todd P. Decomposition and crossover effects in the theory of planned behaviour: a study of consumer adoption intentions. International Journal Research in Marketing. 1995;12(2):137-155. doi:10.1016/0167-8116(94)00019-K

[11] Hsu MH, Chiu CM. Predicting electronic service continuance with a decomposed theory of planned behaviour. Behaviour and Information Technology. 2004;23(5):359-373. doi:10.1080/0144929041000 1669969

[12] Shih YY, Fang K. The use of a decomposed theory of planned behavior to study Internet banking in Taiwan. Internet Research. 2004;14(3):213-223. doi:http:// dx.doi.org/10.1108/10662240410542643

[13] Mathieson K. Predicting user intentions: comparing the technology acceptance model with the theory of planned behavior. Information Systems Research. 1991;2(3):173-191. doi:http://dx.doi.org/10.1287/ isre.2.3.173

[14] Ajzen I. The theory of planned behaviour. Organizational Behavior and Human Decision Processes. 1991;50(2):179-211. doi:10.1016/07495978(91)90020-T

[15] Burnkrant RE, Page TJ. The structure and antecedents of the normative and attitudinal components of Fishbein's theory of reasoned action. Journal of Experimental Social Psychology. 1988;24(1):66-87. doi:10.1016/0022-1031(88)90044-3

[16] Oliver RL, Bearden WO. Disconfirmation processes and consumer evaluations in product usage. Journal of Business Research. 1985;13(3):235-246. doi: 10.1016/0148-2963(85)90029-3 
[17] Rogers EM. Diffusion of innovations. 2nd ed. New York: The Free Press; 1983.

[18] Rogers EM. Diffusion of innovations. 5th ed. New York: The Free Press; 2003.

[19] Davis FD, Bagozzi RP, Warshaw PR. User acceptance of computer technology: a comparison of two theoretical models. Management Science. 1989;35(8):9821003. doi: http://dx.doi.org/10.1287/mnsc.35.8.982

[20] Moore GC, Benbasat I. Development of an instrument to measure the perceptions of adopting an information technology innovation. Information Systems Research. 1991;2(3):192-222. doi:http://dx.doi.org/10.1287/ isre.2.3.192

[21] Watson RT, Berthon P, Pitt LF, Zinkhan GM. Electronic commerce: the strategic perspective. Dryden Press; 2000.

[22] Bhattancherjee A. Acceptance of e-commerce services: the case of electronic brokerages. IEEE Transactions on Systems, Man, and Cybernetics, Part A: Systems and Humans. 2000;30(4):411-420. doi:10.1109/3468.852435

[23] Gwinner KP, Grelmer DD, Bitner MJ. Relational benefits in services industries: the customer's perspective. Journal of Academy of Marketing Science. 1998;26(2):101114. doi: $10.1177 / 0092070398262002$

[24] Garbarino E, Johnson MS. The different roles of satisfaction, trust and commitment in customer relationships. Journal of Marketing. 1999;63(2):70-87. doi:10.2307/1251946

[25] Singh J, Sirdeshmukh D. Agency and trust mechanisms in relational exchanges. Journal of the Academy of Marketing Science. 2000;28(1):150-167. doi:10.1177/0092070300281014

[26] Cronin JJ, Brady MK, Hult GTM. Assessing the effects of quality, value and customer satisfaction on consumer behavioural intentions in service environments. Journal of Retailing. 2000;76(2):193-218. doi:10.1016/ S00224359(00)00028-2

[27] Bolton RN, Drew JH. A longitudinal analysis of the impact of service changes on customer attitudes. Journal of Marketing. 1991;55(1):1-9. doi:10.2307/1252199

[28] Hutchinson J, Lai F, Wang Y. Understanding the relationships of quality, value, equity, satisfaction, and behavioural intentions among golf travellers. Tourism Management. 2009;30(2):298-308. doi:10.1016/ j.tourman.2008.07.010

[29] Zuker LG. Production of trust: institutional sources of economic structure. Research in Organizational Behaviour. 1986;8:53-111.
[30] Novak TP, Hoffman DL, Yung YF. Measuring the customer experience in online environments: a structural modelling approach. Marketing Science. 1999;19(1):22-42. doi:http://dx.doi.org/10.1287/ mksc.19.1.22.15184

[31] Yoon SJ. The antecedents and consequences of trust in online-purchase decisions. Journal of Interactive Marketing. 2002;16(2):47-63. doi:10.1002/dir.10008

[32] Awad NF, Ragowsky A. Establishing trust in electronic commerce through online word of mouth: an examination across genders. Journal of Management Information Systems, 2008;24(4):101-121. doi:10.2753/ MIS0742-1222240404

[33] Aaker DA. Measuring brand equity and across product and markets. California Management Review. 1996;38(3):102-120. doi:10.2307/41165845

[34] Ajzen I. Perceived behavioural control, self-efficacy, locus of control, and the theory of planned behaviour. Journal of Applied Social Psychology. 2002;32(4):665683. doi:10.1111/j.1559-1816.2002.tb00236.x

[35] ZeithamI VA, Bitner MJ. Service marketing: integrating customer focus across the firm. 2nd ed. Boston: McGraw Hill; 2000.

[36] Anderson EW, Fornell C, Mazvancheryl SK. Customer satisfaction and shareholder value. Journal of Marketing. 2004;68(4):172-185. doi:http://dx.doi. org/10.1509/jmkg.68.4.172.42723

[37] McKnight DH, Kacmar CJ, Choudhury V. Shifting factors and the ineffectiveness of third party assurance seals: a two-stage model of initial trust in a web business. Electronic Markets. 2004;14(3):252-266. doi:10.108/1019678042000245263

[38] Hu LT, Bentler PM, Kano Y. Can test statistics in covariance structure analysis be trusted. Psychological Bulletin. 1992;112(2):351-362. doi:http://dx.doi. org/10.1037/0033-2909.112.2.351

[39] Bagozzi RP, Yi Y. On the evaluation of structural equation models. Journal of the Academy of Marketing Science. 1988;16(1):74-94. doi:10.1007/BF02723327

[40] Fornell C, Lacrker DF. Evaluating structural equation models with unobservable and measurement errors. Journal of Marketing Research. 1981;18(1):39-50. doi:10.2307/3151312

[41] Hair JF, Anderson RE, Tatham RL, Black WC. Multivariate data analysis. $5^{\text {th }}$ ed. New Jersey: Prentice-Hall International; 1998. 